\title{
Woody neotropical streetscapes: a case study of tree and shrub species richness and composition in Xalapa
}

\section{Paisajes urbanos leñosos en el Neotrópico: Riqueza y composición de especies de árboles y arbustos en Xalapa}

\author{
Ina Falfán' and lan MacGregor-Fors ${ }^{*}$
}

1 Red de Ambiente y Sustentabilidad. Instituto de Ecología, A.C., Veracruz, México.

* Corresponding author. ian.macgregor@inecol.mx

\begin{abstract}
The urbanization process goes far beyond the replacement of preexisting non-urban systems, transforming the land in such way that represents worrisome ecological threats. In the novel urban systems, original vegetation is removed and/or replaced with a combination of native and exotic species. In this study, our aim was to generate an updated species list of the trees and shrubs that thrive in the streetscape of Xalapa (Veracruz, Mexico), describing their native/exotic ratio. For this, we followed a city-wide approach comprised by a grid of 106 sampling sites. We recorded a total of 140 tree and shrub species, of which 32 had not been previously reported for the city. Exotics represented more than half of the recorded species, which together with native ones were distributed unevenly throughout the city. Most frequent species include: Weeping Fig (Ficus benjamina), Chinese Hibiscus (Hibiscus rosa-sinensis), Paperflower (Bougainvillea glabra), Rhododendron (Rhododendron sp.), Mexican Cypress (Cupressus lusitanica), and Little-leaf Boxwood (Buxus microphylla). It is noticeable that sites at which we recorded no trees or shrubs were located near downtown and peripheral areas of the city. Our findings should be considered carefully, as the unequal distribution of plant diversity in urban areas can compromise the benefits that vegetation provides to citizens, as well as their ecological functions.
\end{abstract}

KEYWORDS: exotic species, native species, spatial distribution, species origin, street trees, urban trees.

\section{RESUMEN}

El proceso de urbanización va más allá del remplazo de sistemas preexistentes, transformando el terreno de tal forma que representa amenazas ecológicas preocupantes. En estos nuevos sistemas, la vegetación original es removida o remplazada con una combinación de especies nativas y exóticas. Este trabajo se enfocó en generar una lista de especies actualizada de los árboles y arbustos del paisaje urbano de Xalapa (Veracruz, México), describiendo la proporción de especies nativas y exóticas. Para ello, se utilizó un enfoque de ciudad completa comprendida por una retícula de 106 sitios de muestreo. Se registró un total de 140 especies de árboles y arbustos, de los cuales 32 no habían sido registrados anteriormente para la ciudad. Las especies exóticas representaron más de la mitad de las especies registradas, las cuales en conjunto con las especies nativas estuvieron distribuidas de forma desigual a lo largo y ancho de la ciudad. Las especies más frecuentes fueron: laurel de la India (Ficus benjamina), tulipán chino (Hibiscus rosa-sinensis), buganvilia (Bougainvillea glabra), azalea (Rhododendron sp.), cedro blanco (Cupressus lusitanica) y boj de hoja pequeña (Buxus microphylla). Es notable que los sitios en los que no se registró ninguna especie de árbol o arbusto estuvieron localizados cerca del centro histórico de la ciudad, así como en sus periferias. Los resultados de este trabajo deben ser considerados cuidadosamente, ya que la distribución desigual de la diversidad de plantas en áreas urbanas puede comprometer los beneficios que provee la vegetación a los habitantes, así como sus funciones ecológicas.

Palabras Clave: especies exóticas, especies nativas, distribución espacial, origen de especie, arbolado de alineación, árboles urbanos. 


\section{INTRODUCTION}

Urbanization is a process in which humans establish and develop cities (Vlahov and Galea, 2002; Berkowitz et al., 2003; United Nations, 2014). This process implies the transformation of preexisting non-urban systems into urban novel ones with unique physical, biological, and social traits (Alberti et al., 2003; Grimm et al., 2008; Pickett et al., 2011). In general, urban areas are established to fulfill human modern housing needs, which have varied along regions and through time (Berry, 2008). Thus, as the urbanization process tends to replace original vegetation, as well as many other important local changes, it represents a threat for biodiversity in larger scales (Czech and Krausman, 1997; Czech et al., 2000; McKinney, 2006; Kowarik, 2011; Aronson et al., 2014).

As a crucial ecological component of urban areas, its vegetation provides important social and environmental benefits to urban dwellers (Dwyer et al., 1992; Tyrväinen et al., 2005; Manning, 2008), as well as a wide array of resources for wildlife species that dwell within cities (Ortega-Álvarez and MacGregor-Fors, 2011; Antonini et al., 2013; Ramírez-Restrepo and Halffter, 2013; Lintott et al., 2014). Moreover, it is noteworthy that tree and shrub diversity, composition, cover, and spatial distribution within a city are basically driven by the interaction between physical (e.g., topography), ecological (e.g., preexistent vegetation type) and human factors (e.g., planting, pruning, preference for some species, socioeconomics; Zipperer et al., 1997; Dwyer et al., 2000; Ramage et al., 2013), often representing part of the identity of cities (Konijnendijk, 2008; Li et al., 2011). In general, urban trees and shrubs are located on sidewalks, median strips, and urban greenspaces (e.g., woodlands, parks, cemeteries, gardens; Konijnendijk et al., 2005; Ardila et al., 2012), commonly aggregated and distributed unevenly throughout cities (Escobedo and Nowak, 2009; McConnachie and Shackleton, 2010; Cohen et al., 2012).

Although urban vegetation has received important attention by urban ecologists in the past (Rowntree, 1984; Jim, 1988; Zipperer et al., 1997; Luck et al., 2009; Ortega-Álvarez et al., 2011), little is known about their ecolog- ical patterns and processes in highly biodiverse regions; woefully, Latin America is not an exception (MacGregor-Fors and Ortega-Álvarez, 2013; Pauchard and Barbosa, 2013). Although many studies on trees and shrubs in Mexican urban areas have been concentrated in Mexico City (e.g., Díaz-Betancourt et al., 1987; Cruz, 1989; López-Moreno and Díaz-Betancourt, 1989; LópezMoreno, 1991; Chacalo and Corona, 2009; Ortega-Álvarez et al., 2011), there is a growing number of studies focusing on different aspects of urban trees and shrubs (e.g., diversity, origin, spatial distribution, environmental function, landscape architecture, management, social perception) in other cities, such as: Monterrey, Nuevo León (Alanís, 2005); Mérida, Yucatán (Sosa and Flores, 1993; Orellana et al., 2003; López-Falfán, 2008); Campeche, Campeche (Niembro-Rocas, 1992); Chihuahua, Chihuahua (Alcalá et al., 2008); Morelia, Michoacán (Conejo, 2011; Sánchez and Peralta, 2013; Camacho-Cervantes et al., 2014); and Xalapa, Veracruz (Arias, 1983; García-Campos, 1993; Ruiz-Montiel et al., 2014).

Particularly, the city of Xalapa-Enriquez (referred to as Xalapa hereafter) has recently received special attention as it represents an excellent urban laboratory due to its location and orography that promote highly biodiverse wildlife communities (Capitanachi et al., 2001; Williams-Linera et al., 2002; MacGregor-Fors et al., 2015). Previous studies have assessed the woody vegetation of Xalapa in specific areas of the city, most of which include greenspaces (e.g., Arias, 1983; García-Campos, 1993; Díaz-Betancourt and López-Moreno, 1993; Capitanachi and Amante, 1995; SCDEPEV, 2010; Lemoine, 2012; Ruiz-Montiel et al., 2014); however, there is an important dearth of knowledge regarding the woody vegetation along its streetscapes, including its spatial distribution.

In this study, we focused on the streetscape of Xalapa using a city-wide survey approach. City-wide surveys take into account the spatial heterogeneity of the ecological, infrastructure, and social conditions of the city, allowing studies to have a representative sample of its most frequent scenarios (Turner, 2003; Davies et al., 2011; McCaffrey and Mannan, 2012). Based on previous studies, we 
expected that the surveyed trees and shrubs would show: (1) low species richness (López-Moreno and Díaz-Betancourt, 1991; Li et al., 2011; Yang et al., 2012), (2) high representation of exotic species (Castillo-Campos, 1991; López-Moreno and Díaz-Betancourt, 1991; KuruneriChitepo and Shackleton, 2011; Wang et al., 2012), and (3) an uneven distribution of richness across the city (Landry and Chakraborty, 2009; Kuruneri-Chitepo and Shackleton, 2011; Kendal et al., 2012).

\section{OBJECTIVES}

To generate an updated species list of trees and shrubs of the streetscape of Xalapa based on a city-wide approach, describing their native/exotic ratio.

\section{MATERIALS AND METHODS}

\section{Study area}

We performed this study in the city of Xalapa (19³2'37" $\left.\mathrm{N}, 96^{\circ} 54^{\prime} 37^{\prime} \mathrm{W}\right)$, including its conurbation with Banderilla (Municipality of Banderilla), Guadalupe Victoria (Municipality of Tlalnehuayocan), and Bugambilias
(Municipality of Emiliano Zapata). The urban continuum of Xalapa has a territory of $\sim 60 \mathrm{~km}^{2}$ and is an updated version of that proposed by Lemoine (2012), based on MacGregor-Fors (2010), and current ongoing research (Muñoz-Robles et al., unpublished data) (Fig. 1). Following its $600 \mathrm{~m}$ elevation gradient $(1120 \mathrm{~m}-1720 \mathrm{~m}$ asl; Inegi, 2009), Xalapa has a semicalid climate on its southeast side, while a temperate climate dominates its northwestern section (Soto and Gómez, 1993). The original vegetation of the region was diverse, comprised mainly of pine forests, oak forests, cloud forests, and tropical dry forests (CastilloCampos, 1991). Currently, $20 \%$ of the city's area is covered by woody vegetation (Lemoine, 2012) and, as in many other cities in the world, it is comprised of a mixture of native and exotic species, basically confined to greenspaces (e.g., parks, streets, gardens; Castillo-Campos, 1991; García-Campos, 1993; Ruiz-Montiel et al., 2014).

\section{Field surveys and plant identification}

To establish sampling sites across Xalapa, we used a polygon of the city from ongoing research (Muñoz-Robles et al., unpublished data). Briefly, we delimited the polygon of

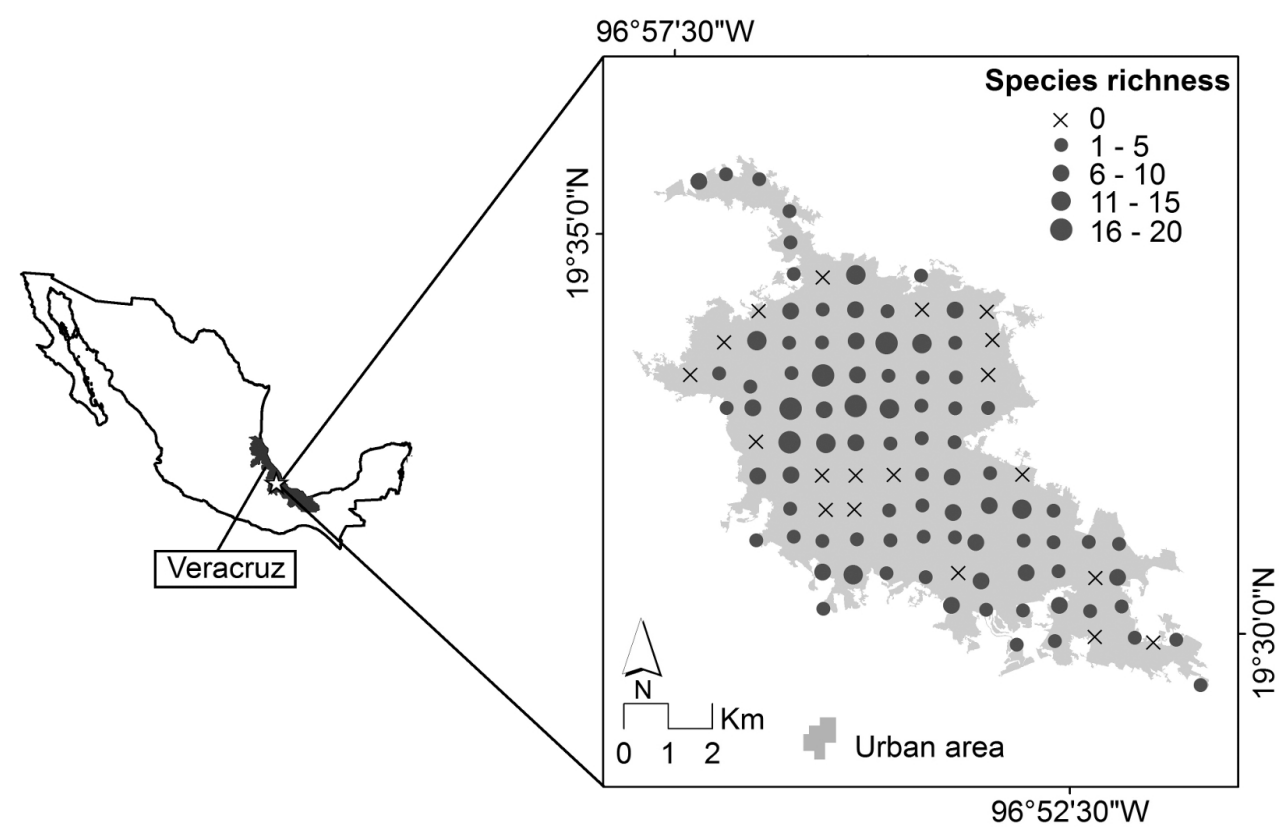

Figure 1. Map of study area depicting the location of Xalapa in central Veracruz and the distribution of surveyed tree and shrub species richness throughout the city. 
Xalapa following spatial aggregation and communication criteria on an up-to-date high-quality satellite image. We then set a $750 \mathrm{~m} \times 750 \mathrm{~m}$ grid on the polygon of the city and considered the centroid of cells as sampling sites. Finally, we adjusted the position of sampling sites in situ to the nearest accessible public area where sampling was feasible. The resulting number of sampling sites was 110 , which for security reasons at some peri-urban areas of the city was reduced to 106 (Fig. 1).

We surveyed trees and shrubs in 106 sites, identifying all species present in an area of $150 \mathrm{~m}^{2}$ per site. Due to the complexity of urban areas and their streetscapes, we used three procedures depending on the nature of the sampling site, considering the same survey area: (1) two $75 \mathrm{~m}$ transects on both sidewalks of streets without median-strips, (2) three $50 \mathrm{~m}$ transects on both sidewalks and the median-strip, when the latter were present, and (3) two $50 \mathrm{~m}$ transects on both sides of pathways of greenspaces and a parallel one $5 \mathrm{~m}$ away from the pathway.

All trees (including palms) and shrubs (including hedges) inside the surveyed area were recorded and identified to species level, whenever possible. When we were not able to identify an individual in the field, we collected a sample for further identification in the herbarium (Herbario XAL, Inecol). We identified the recorded trees and shrubs using available identification keys and specialized literature (Arias, 1983; Benítez et al., 2004; Calderón and Rzedowski, 2005; Pennington and Sarukhán, 2005; Vásquez, 2007; Chacalo and Corona, 2009; the "Flora de Veracruz" series; and those in www.tropicos.org). Some species that could not be determined in the herbarium were identified by an expert botanist (G. Castillo-Campos, pers. com.). Nevertheless, three tree individuals could not be identified as we could not get a field sample during the fieldwork due to their height and/or location. We will deposit all collected samples with herbarium minimum requirements in the Herbarium XAL (Inecol).

\section{Data analysis}

Although we could not identify all recorded trees and shrubs to species level, we considered all identified taxa as species because we are certain that they belong to different species. After identifying all recorded tree and shrub species, we determined their origin and categorized them in native and exotic. We based the native/exotic categorization in relation to the region of study (central Veracruz), considering species as exotic if they do not occur naturally in central Veracruz (Richardson et al., 2000; Lodge and Shrader-Frechette, 2003; Jørgensen and Fath, 2008). We also contrasted our results with those reported in previous studies considering taxonomical changes in a world-wide database (Tropicos: www.tropicos.org). In order to set our species list into context, we compared it with previous local and regional studies (Arias, 1983; García-Campos, 1993; Díaz-Betancourt and López-Moreno, 1993; Capitanachi and Amante, 1995; SCDEPEV, 2010; Lemoine, 2012; Ruiz-Montiel et al., 2014).

We used basic statistics to describe average, standard deviation, and data distribution of tree and shrub richness species recorded per sampling site. We carried out a two-sample Kolmogorov-Smirnov test to compare the distributions of the proportions of both native and exotic species. Due to the non-normality of our data (i.e., native and exotic tree and shrub species richness assessed with one sample Kolmogorov-Smirnov test: $\mathrm{D}=0.60, \mathrm{P}<$ 0.001; D = 074, P < 0.001, respectively), we carried out a Wilcoxon rank-sum test for paired data to compare the values of native and exotic richness. We performed all statistical procedures in $\mathrm{R}$ ( $\mathrm{R}$ Development Core Team, 2012).

\section{RESULTS}

We recorded a total of 1116 trees and shrubs in our citywide survey. Of them, we identified 140 species (Table 1), 126 to the species level, eight to genus, and three to family, while three specimens could not be identified at all, reason why they were not considered in further analyses. From the 49 recorded families, the one with highest representation was Arecaceae (12 species), followed by Fabaceae (10 species), Fagaceae (9 species), and Malvaceae (8 species). It is noteworthy that almost half $(47 \%)$ of the recorded families were represented by a single species. In 
relation to their distribution in the city, the six most frequent species were: Weeping Fig (Ficus benjamina; 32\% of the sampling sites), Chinese Hibiscus (Hibiscus rosa-sinensis; $19 \%$ of the sampling sites), Paper Flower (Bougainvillea glabra; $15 \%$ of the sampling sites), Rhododendron (Rhododendron sp.; $15 \%$ of the sampling sites), Mexican Cypress (Cupressus lusitanica; 15\% of the sampling sites), and Little-leaf Boxwood (Buxus microphylla; $15 \%$ of the sampling sites; Fig. 2, Table 1).

From the trees and shrubs we could identify and relate to their geographical origin ( $\mathrm{n}=131$ species), $55.7 \%$ are exotic and $44.3 \%$ are original of central Veracruz. When considering the six most frequent species (found in $>15$ sampling sites), only one is native to central Veracruz (Mexican Cypress-Cupressus lusitanica). An important difference found between the surveyed sites from greenspaces (i.e., Cerro de la Galaxia, Cerro Macuiltepetl, Ecologic Reserve Tejar-Garnica, Seminario Mayor, Parque Natura) and the rest of highly developed urban areas was a higher presence of native tree and shrub species $68 \%$ in five greenspaces; 36\% in 101 highly developed urban sites).

Regarding all tree and shrub species richness across Xalapa, we recorded values ranging from $0-20$ species per

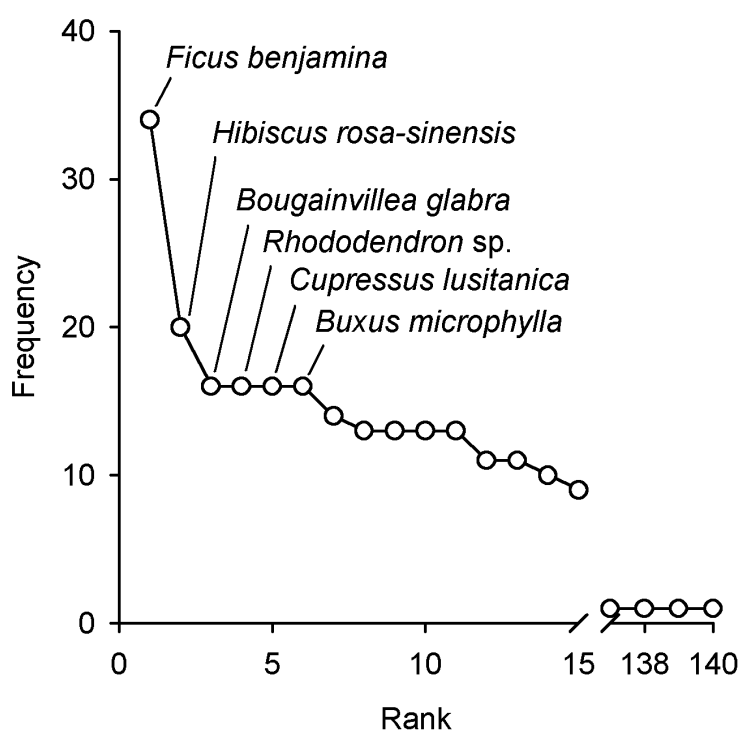

Figure 2. Rank-frequency plot of surveyed tree and shrub species in Xalapa. sampling site, with an average of $4.8( \pm$ SD 4.9$)$ species. After excluding the 19 sites where we did not record any tree or shrub (located basically in the downtown and peripheral areas of the city; Fig. 1), native tree and shrub richness per sampling site ranged from 0-10 species, with an average of 1.8 ( \pm SD 2.1) species. Contrastingly different to native species, exotic species richness was higher, with up to 15 species per sampling site (average: $3.9 \pm$ SD 3.7 species). According to the Wilcoxon rank-sum test for paired data, significant differences exist between the amount of native and exotic species per sampling site, with the later showing higher numbers $(\mathrm{V}=661.5, \mathrm{P}<0.001)$.

As predicted, the spatial distribution of tree and shrub species richness showed to be unequally distributed across the city, with the richest sites (with $>15$ tree and shrub species) located in the northern part of the city (Fig.1). Interestingly, sampling sites with the highest values of exotic species were also located in the northern-central portion of the city (Fig. 3). We found no clear spatial distribution patterns for neither native nor exotic species richness across the city (Fig. 3). Still, the few sampling sites at which we recorded $100 \%$ native trees and shrubs are mainly located on peripheral areas of Xalapa, while those where we recorded $100 \%$ exotic trees and shrubs are dispersed throughout the city (Fig. 4). Although the proportion of recorded native and exotic tree and shrub species ranged from $0 \%-100 \%$ per site, the average percentage of exotics was of $65.7 \%( \pm$ SD $31.7 \%$ species), and was of $33.0 \%$ ( \pm SD $31.4 \%$ ) for natives, with the frequency distribution of native/exotic ratios showing significant differences (two-sample Kolmogorov-Smirnov test: $\mathrm{D}=0.44, \mathrm{P}<0.001$; Fig. 4).

\section{DISCUSSION AND CONCLUSION}

Urban vegetation is dynamic due to the human forces behind its presence and abundance (McPherson et al., 1997; Zipperer et al., 1997; Hope et al., 2006; Ortega-Álvarez et al., 2011; Ramage et al., 2013). Our results show that tree and shrub species richness of the streetscape of Xalapa is high, with an important exotic component, and unevenly distributed across the city. Due to the human forces driving its streetscape, the unique location of the 
TABLE 1. List of recorded tree and shrub species in the streestscape of Xalapa, Veracruz, ordered alphabetically by family.

\begin{tabular}{|c|c|c|c|}
\hline Family & Species & Origin' & Frequency ${ }^{2}$ \\
\hline Acanthaceae & Pachystachys lutea Ness c, d & Exotic & 2 \\
\hline \multirow[t]{2}{*}{ Adoxaceae } & Sambucus nigra L.: & Native & 4 \\
\hline & Viburnum suspensum Lindl.: & Exotic & 3 \\
\hline Altingiaceae & Liquidambar styraciflua $\mathrm{L} . \mathrm{a}, \mathrm{b}, \mathrm{c}, \mathrm{d}, \mathrm{e}, \mathrm{f}, \mathrm{g}$ & Native & 9 \\
\hline \multirow[t]{2}{*}{ Anacardiaceae } & Mangifera indica $L_{\text {. }} \mathrm{a}, \mathrm{b}, \mathrm{c}, \mathrm{e}$ & Exotic & 1 \\
\hline & Spondias purpurea L. ${ }^{\mathrm{c}}$ & Native & 1 \\
\hline Annonaceae & Annona cherimola Mill. ${ }^{\mathrm{a}, \mathrm{b}, \mathrm{d}, \mathrm{e}, \mathrm{g}}$ & Native & 2 \\
\hline Apocynaceae & Nerium oleander $L . b, c, d$ & Exotic & 7 \\
\hline \multirow[t]{4}{*}{ Araliaceae } & Dendropanax arboreus (L.) Decne. \& Planch. a, b & Native & 1 \\
\hline & Oreopanax xalapensis (Kunth) Decne. \& Planch. ${ }^{\mathrm{a}, \mathrm{b}, \mathrm{d}, \mathrm{g}}$ & Native & 1 \\
\hline & Schefflera actinophylla (Endl.) Harms* & Exotic & 2 \\
\hline & Schefflera arboricola (Hayata) Merr. c, d, e & Exotic & 5 \\
\hline Araucariaceae & Araucaria heterophylla (Salisb.) Franco a, b, d,e,f & Exotic & 2 \\
\hline \multirow[t]{12}{*}{ Arecaceae } & Arecaceae sp. 1 & - & 1 \\
\hline & Arecaceae sp. 2 & - & 1 \\
\hline & Caryota urens L. d,e & Exotic & 1 \\
\hline & Chamaedorea elegans Mart. c,d & Native & 3 \\
\hline & Chamaedorea klotzschiana H. Wendl.. & Native & 1 \\
\hline & Chamaedorea schiedeana Mart. ${ }^{\mathrm{b}}$ & Native & 1 \\
\hline & Chamaedorea sp. & Native & 1 \\
\hline & Dypsis lutescens (H. Wendl.) Beentje \& J. Dransf. d,e & Exotic & 5 \\
\hline & Elaeis guineensis Jacq. & Exotic & 1 \\
\hline & Hyophorbe sp." & Exotic & 1 \\
\hline & Syagrus romanzoffiana (Cham.) Glassman* & Exotic & 7 \\
\hline & Washingtonia robusta $\mathrm{H}$. Wendl. $\mathrm{a}, \mathrm{b}, \mathrm{d}$ & Exotic & 1 \\
\hline \multirow[t]{3}{*}{ Asteraceae } & Dahlia imperialis Roezl ex Ortgies ${ }^{d}$ & Exotic & 1 \\
\hline & Verbesina turbacensis Kunth* & Native & 1 \\
\hline & Vernonia patens Kunth* & Native & 6 \\
\hline Betulaceae & Carpinus caroliniana Walter ${ }^{a}, \mathrm{~b}, \mathrm{~d}, \mathrm{e}, \mathrm{f,g}$ & Native & 3 \\
\hline \multirow[t]{3}{*}{ Bignoniaceae } & Jacaranda mimosifolia D. Don a,b,c,d,e,f & Exotic & 11 \\
\hline & Spathodea campanulata P. Beauv. ${ }^{a, b, d, e, f}$ & Exotic & 3 \\
\hline & Tabebuia sp." & Native & 1 \\
\hline Burseraceae & Bursera simaruba (L.) Sarg. b,c,d,g & Native & 5 \\
\hline Buxaceae & Buxus microphylla Siebold \& Zucc. b, d & Exotic & 16 \\
\hline \multirow[t]{2}{*}{ Casuarinaceae } & Casuarina cunninghamiana Miq. ${ }^{\mathrm{d}, \mathrm{e}, \mathrm{f}, \mathrm{g}}$ & Exotic & 3 \\
\hline & Casuarina equisetifolia $\mathrm{L}$. $a, b, c, d, f$ & Exotic & 1 \\
\hline Celastraceae & Euonymus japonicus Thunb. b,d & Exotic & 1 \\
\hline Clethraceae & Clethra macrophylla M. Martens \& Galeotti d, f & Native & 2 \\
\hline
\end{tabular}


TABLE 1. List of recorded tree and shrub species in the streestscape of Xalapa, Veracruz, ordered alphabetically by family. (Continued...)

\begin{tabular}{|c|c|c|c|}
\hline Family & Species & Origin 1 & Frequency ${ }^{2}$ \\
\hline Cornaceae & Cornus florida L." & Native & 1 \\
\hline \multirow[t]{5}{*}{ Cupressaceae } & Callitropsis macrocarpa (Hartw. ex Gordon) D.P. Little* & Exotic & 2 \\
\hline & Chamaecyparis pisifera (Siebold \& Zucc.) Endl. b, d,e,f & Exotic & 5 \\
\hline & Cupressus lusitanica Mill. a, b, c, d, e, f, g & Native & 16 \\
\hline & Cupressus sempervirens L. $a, c, d, e$ & Exotic & 4 \\
\hline & Platycladus orientalis (L.) Franco ${ }^{\mathrm{c}, \mathrm{d}}$ & Exotic & 2 \\
\hline Ericaceae & Rhododendron sp. ${ }^{c, d^{* *}}$ & Exotic & 16 \\
\hline \multirow[t]{4}{*}{ Euphorbiaceae } & Codiaeum variegatum (L.) Rumph. ex A. Juss. c, d & Exotic & 3 \\
\hline & Croton draco Schltdl. \& Cham. a, b, e, g & Native & 1 \\
\hline & Euphorbia cotinifolia L. a, b, c, d,e,g & Native & 6 \\
\hline & Euphorbia pulcherrima Willd. ex Klotzsch b,c,d & Exotic & 5 \\
\hline \multirow[t]{10}{*}{ Fabaceae } & Acacia pennatula (Schltdl. \& Cham.) Benth. a, b, c, e, g & Native & 6 \\
\hline & Bauhinia variegata $L$. b,c,d & Exotic & 1 \\
\hline & Caesalpinia pulcherrima (L.) Sw." & Native & 1 \\
\hline & Calliandra houstoniana (Mill.) Standl.* & Native & 1 \\
\hline & Cassia fistula L." & Exotic & 1 \\
\hline & Erythrina americana Mill. a,b, d,e,g & Native & 6 \\
\hline & Inga inicuil Schltdl. \& Cham. ex G. Don a, b, c, d, e, f, g & Native & 1 \\
\hline & Leucaena diversifolia (Schltdl.) Benth. d,f & Native & 1 \\
\hline & Senna septemtrionalis (Viv.) H.S. Irwin \& Barneby* & Native & 1 \\
\hline & Senna sp. & - & 1 \\
\hline \multirow[t]{9}{*}{ Fagaceae } & Quercus acutifolia Née a,b, e,g & Native & 1 \\
\hline & Quercus aff. acutifolia Née a, b,e, g & Native & 1 \\
\hline & Quercus castanea Née g & Native & 1 \\
\hline & Quercus cortesii Liebm." & Native & 1 \\
\hline & Quercus germana Schltdl. \& Cham. a,b,e, g & Native & 2 \\
\hline & Quercus peduncularis Née* & Native & 1 \\
\hline & Quercus sapotifolia Liebm.. & Native & 1 \\
\hline & Quercus sartorii Liebm.* & Native & 1 \\
\hline & Quercus xalapensis Bonpl. e, f, g & Native & 1 \\
\hline Juglandaceae & Juglans pyriformis Liebm. ${ }^{\mathrm{d}, \mathrm{e}}$ & Native & 1 \\
\hline Lamiaceae & Rosmarinus officinalis L. c, d & Exotic & 2 \\
\hline \multirow[t]{2}{*}{ Lauraceae } & Cinnamomum verum J. Presl ${ }^{*}$ & Exotic & 2 \\
\hline & Litsea glaucescens Kunth c, d, e & Native & 2 \\
\hline
\end{tabular}

\footnotetext{
'Origin: native/exotic in relation to central Veracruz.

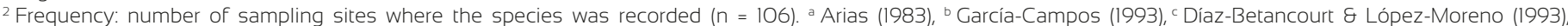

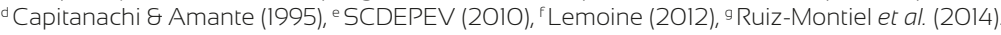

"Not previously reported to the urban area of Xalapa.

*These two shrubs may comprise several taxonomic entities, nevertheless, for practical matters, we report them here as one unknown species.
} 
TAвLE 1. List of recorded tree and shrub species in the streestscape of Xalapa, Veracruz, ordered alphabetically by family. (Continued...)

\begin{tabular}{|c|c|c|c|}
\hline Family & Species & Origin $^{1}$ & Frequency ${ }^{2}$ \\
\hline Lauraceae & Persea americana Mill. a, b, c, d,e,g & Native & 6 \\
\hline \multirow[t]{2}{*}{ Lythraceae } & Lagerstroemia indica $\mathrm{L} . \mathrm{b,d}$ & Exotic & 3 \\
\hline & Punica granatum L. c, d & Exotic & 2 \\
\hline \multirow[t]{11}{*}{ Magnoliaceae } & Magnolia grandiflora L. ${ }^{a, b, d, e}$ & Native & 3 \\
\hline & Magnolia schiedeana Schltdl. ${ }^{d}$ & Native & 1 \\
\hline & Magnolia soulangeana Soul.-Bod. b,d & Exotic & 1 \\
\hline & Ceiba aesculifolia (Kunth) Britten \& Baker f. d & Native & 1 \\
\hline & Ceiba sp. & - & 1 \\
\hline & Heliocarpus americanus L. ${ }^{g}$ & Native & 3 \\
\hline & Heliocarpus mexicanus (Turcz.) Sprague* & Native & 1 \\
\hline & Hibiscus radiatus Cav.* & Exotic & 1 \\
\hline & Hibiscus rosa-sinensis L. b, c, d, g & Exotic & 20 \\
\hline & Hibiscus syriacus L. ${ }^{b}$ & Exotic & 1 \\
\hline & Malvaviscus arboreus Cav. b, c, d, f, g & Native & 2 \\
\hline Melastomataceae & Tibouchina urvilleana (DC.) Cogn. ${ }^{\mathrm{b}, \mathrm{d}}$ & Exotic & 1 \\
\hline \multirow[t]{2}{*}{ Meliaceae } & Melia azedarach L. a,b, d, e & Exotic & 3 \\
\hline & Trichilia havanensis Jacq. ${ }^{\mathrm{a}, \mathrm{b}, \mathrm{c}, \mathrm{d}, \mathrm{e}, \mathrm{g}}$ & Native & 5 \\
\hline \multirow[t]{4}{*}{ Moraceae } & Ficus benjamina L. b,c, d, e,f & Exotic & 34 \\
\hline & Ficus carica $\mathrm{L}^{\mathrm{c}, \mathrm{d}, \mathrm{e}}$ & Exotic & 1 \\
\hline & Ficus elastica Roxb. ex Hornem. a, b, d, e & Exotic & 1 \\
\hline & Ficus microcarpa L. f. a, b, d, e & Exotic & 6 \\
\hline \multirow[t]{7}{*}{ Myrtaceae } & Callistemon citrinus (Curtis) Skeels $a, b, c, d, e, f$ & Exotic & 4 \\
\hline & Eucalyptus camaldulensis Dehnh.* & Exotic & 2 \\
\hline & Eugenia uniflora L.* & Exotic & 1 \\
\hline & Pimenta dioica (L.) Merr. a, b,c, d,e & Native & 2 \\
\hline & Psidium cattleyanum Sabine ${ }^{*}$ & Exotic & 1 \\
\hline & Psidium guajava L. $a, b, c, d, e, g$ & Native & 13 \\
\hline & Syzygium samarangense (Blume) Merr. \& L.M. Perry b, d, e & Exotic & 10 \\
\hline \multirow[t]{2}{*}{ Nyctaginaceae } & Bougainvillea buttiana Holttum \& Standl. ${ }^{c}$ & Exotic & 5 \\
\hline & Bougainvillea glabra Choisy ${ }^{\mathrm{b}, \mathrm{c}}$ & Exotic & 16 \\
\hline \multirow[t]{7}{*}{ Oleaceae } & Fraxinus uhdei (Wenz.) Lingelsh. ${ }^{a, b, c, d, e}$ & Native & 8 \\
\hline & Jasminum mesnyi Hance b,c & Exotic & 1 \\
\hline & Ligustrum japonicum Thunb. b, d & Exotic & 1 \\
\hline & Ligustrum lucidum W.T. Aiton a, b, c, d, e & Exotic & 11 \\
\hline & Ligustrum ovalifolium Hassk. ${ }^{c, d}$ & Exotic & 2 \\
\hline & Ligustrum sinense Lour.* & Exotic & 1 \\
\hline & Ligustrum vulgare L. ${ }^{d}$ & Exotic & 2 \\
\hline Papaveraceae & Bocconia frutescens L. c, d, g & Native & 3 \\
\hline
\end{tabular}


TABLE 1. List of recorded tree and shrub species in the streestscape of Xalapa, Veracruz, ordered alphabetically by family. (End).

\begin{tabular}{|c|c|c|c|}
\hline Family & Species & Origin $^{1}$ & Frequency $^{2}$ \\
\hline Pinaceae & Pinus patula Schltdl. \& Cham. a, b, c, d, e, f, g & Native & 1 \\
\hline Platanaceae & Platanus mexicana Moric. a, b, d, e, f, g & Native & 5 \\
\hline Podocarpaceae & Podocarpus macrophyllus (Thunb.) Sweet ${ }^{*}$ & Exotic & 1 \\
\hline \multirow[t]{2}{*}{ Primulaceae } & Ardisia compressa Kunth* & Native & 2 \\
\hline & Myrsine coriacea (Sw.) R. Br. ex Roem. \& Schult." & Exotic & 2 \\
\hline \multirow[t]{2}{*}{ Proteaceae } & Grevillea robusta A. Cunn. ex R. Br. a, b, d, e,f,g & Exotic & 1 \\
\hline & Macadamia tetraphylla L.A.S. Johnson ${ }^{\text {d }}$ & Exotic & 1 \\
\hline Rhamnaceae & Frangula capreifolia (Schltdl.) Grubov a, b, e, g & Native & 1 \\
\hline \multirow[t]{5}{*}{ Rosaceae } & Eriobotrya japonica (Thunb.) Lindl. a, b, c, d, e,f, g & Exotic & 14 \\
\hline & Prunus persica (L.) Batsch a, b, c, d,e & Exotic & 9 \\
\hline & Prunus sp. & - & 1 \\
\hline & Rosa sp. ${ }^{b, c, d^{* *}}$ & Exotic & 13 \\
\hline & Rosaceae sp. & - & 1 \\
\hline \multirow[t]{4}{*}{ Rubiaceae } & Coffea arabica L. b, c, d, f,g & Exotic & 6 \\
\hline & Gardenia jasminoides J. Ellis b,c,d & Exotic & 3 \\
\hline & Palicourea padifolia (Humb. \& Bonpl. ex Schult.) C.M. Taylor \& Lorence g & Native & 1 \\
\hline & Randia aculeata L.* & Native & 3 \\
\hline \multirow[t]{5}{*}{ Rutaceae } & Casimiroa edulis La Llave ${ }^{a, b, d, e}$ & Native & 1 \\
\hline & Citrus limon (L.) Osbeck a, b, c, d, e, f & Exotic & 6 \\
\hline & Citrus maxima (Burm.) Merr. a, b, c, d, e, g & Exotic & 13 \\
\hline & Citrus reticulata Blanco a, b,c, d, e & Exotic & 13 \\
\hline & Murraya paniculata (L.) Jack c, d & Exotic & 2 \\
\hline$\underline{\text { Salicaceae }}$ & Salix babylonica L. a, b, d, e, g & Exotic & 1 \\
\hline \multirow[t]{2}{*}{ Solanaceae } & Brugmansia candida Pers. ${ }^{\mathrm{b}, \mathrm{d}, \mathrm{g}}$ & Exotic & 6 \\
\hline & Brugmansia suaveolens (Humb. \& Bonpl. ex Willd.) Sweet ${ }^{*}$ & Exotic & 2 \\
\hline Theaceae & Camellia japonica L. b,c,d & Exotic & 2 \\
\hline Verbenaceae & Duranta repens L. ${ }^{\mathrm{b}, \mathrm{d}}$ & Native & 3 \\
\hline \multirow[t]{3}{*}{ Unidentified } & Sp. 1 & - & 1 \\
\hline & Sp. 2 & - & 1 \\
\hline & Sp. 3 & - & 1 \\
\hline
\end{tabular}

'Origin: native/exotic in relation to central Veracruz.

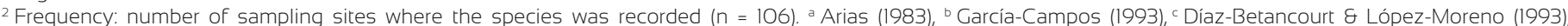

${ }^{d}$ Capitanachi \& Amante (1995), , SCDEPEV (2010), ${ }^{f}$ Lemoine (2012), 9 Ruiz-Montiel et al. (2014).

"Not previously reported to the urban area of Xalapa.

*These two shrubs may comprise several taxonomic entities, nevertheless, for practical matters, we report them here as one unknown species. 

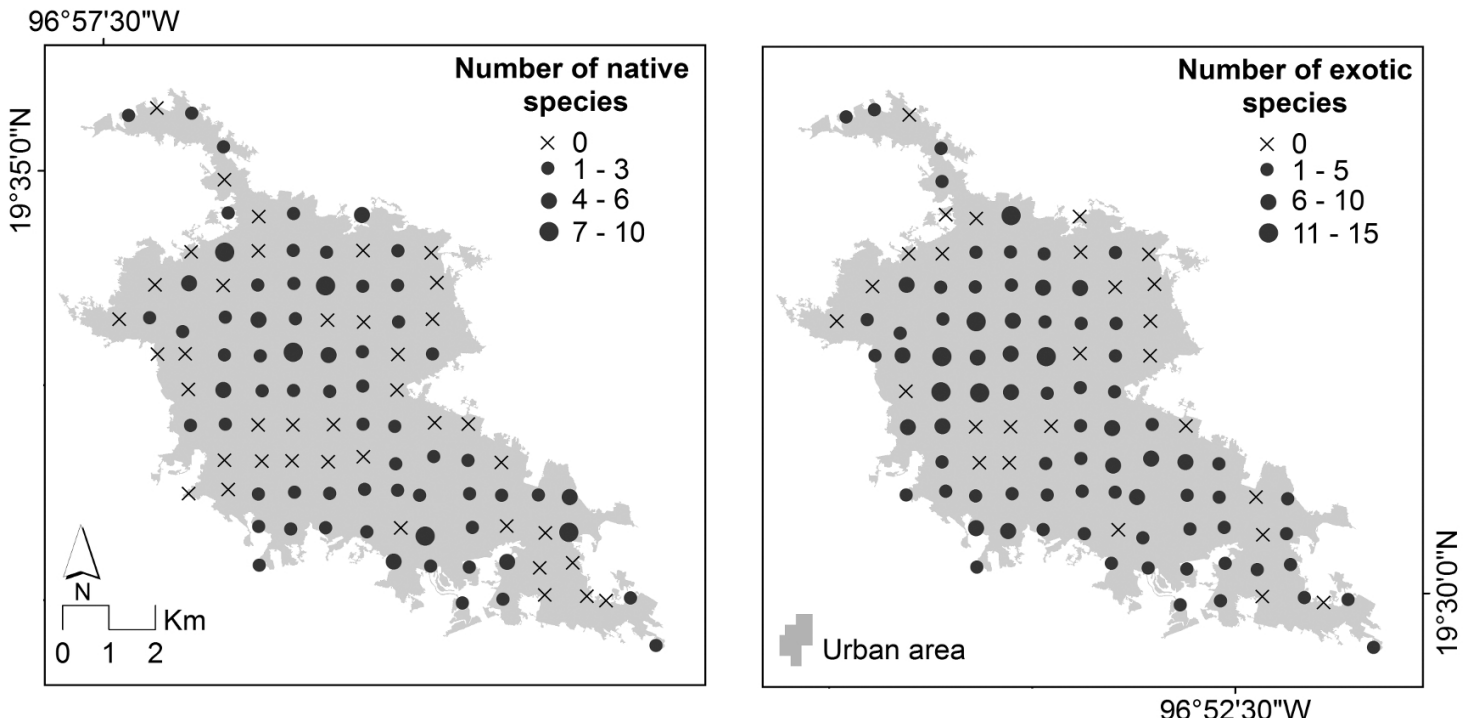

$96^{\circ} 52^{\prime} 30 " \mathrm{~W}$

FIgURE 3. Spatial distribution of native and exotic trees and shrubs recorded in the streetscape of Xalapa.

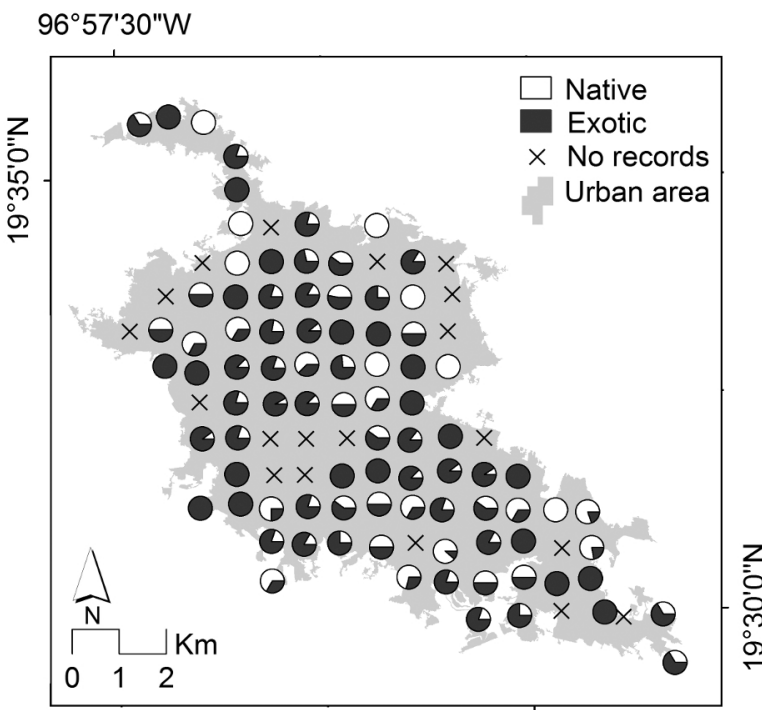

$96^{\circ} 52^{\prime} 30^{\prime \prime} \mathrm{W}$

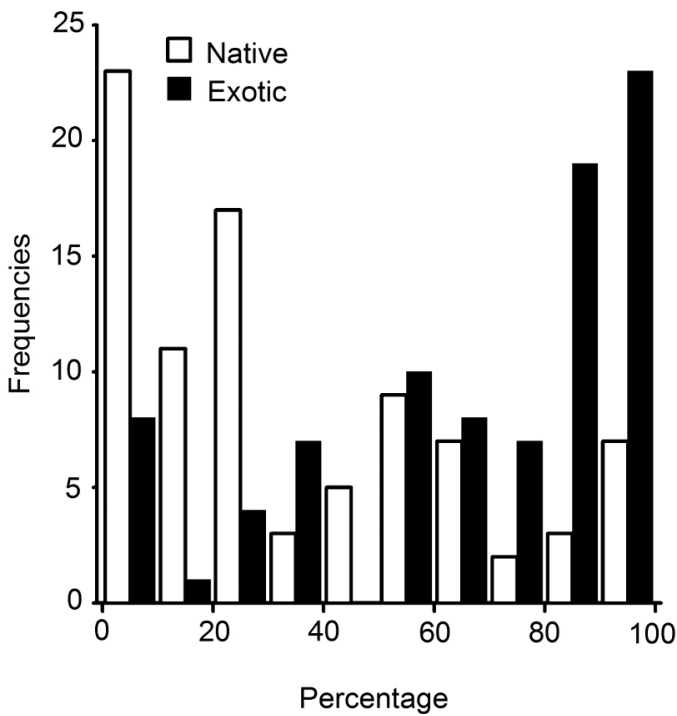

Percentage

Figure 4. Distribution of the origin (native/exotic) of trees and shrubs recorded in the streetscape of Xalapa.

city of Xalapa in a highly biodiverse region did not prevent the replacement of its vegetation in the urbanization process, completely shifting its species composition (Castillo-Campos, 1991; Williams-Linera et al., 2002).

Throughout the globe, street tree species richness varies among urban areas, with some medium-sized cities, as Toledo (Ohio, USA; $225 \mathrm{~km}^{2}$ ) showing high values
(170 species; Subburayalu and Sydnor, 2012), while others, also larger than Xalapa (e.g., Bangalore, India: 740 $\mathrm{km}^{2}$; Curitiba, Brazil: $430 \mathrm{~km}^{2}$; Bangkok, Thailand: $\sim 1570 \mathrm{~km}^{2}$ ) have fewer species $(108,122,127$, respectively; Thaiutsa et al., 2008; Nagendra and Gopal, 2010; Bobrowski and Biondi, 2012) than those we report for Xalapa. Although comparing street tree richness of differ- 
ent cities is complex due to the nature of the surveys, as well as the location of the cities, it is clear that Xalapa has a considerably high number of tree and shrub species richness along its streetscape. When we compared our results with previous studies focused on the urban vegetation of Xalapa, we noted 32 species that had not been previously reported for the city, of which half are native and half are exotic. It is notable that we recorded a higher number of species when compared to a study of vegetation in public spaces of Xalapa (102 tree species; Arias, 1983); nonetheless, the number of species reported in greenspaces of Xalapa is higher (187 tree and shrub species; Capitanachi and Amante, 1995; 185 woody species; García-Campos, 1993). These comparisons show the kind of results that city-wide surveys can provide, often underestimating species from urban greenspaces, which are often unevenly distributed throughout cities (also recorded for other wildlife groups; Nilon et al., 2011).

Previous studies have suggested that urban tree and shrub species composition changes with time (LópezMoreno and Díaz-Betancourt, 1991; Dwyer et al., 2000; Alanís, 2005). In Xalapa, this is the case of the exotic Weeping Fig (F. benjamina), by far the most frequent species of the streetscape of Xalapa (Fig. 2). This exotic species is not reported by Arias (1983), but is reported in the subsequent published literature of urban vegetation for the city. Regardless that this species has caused urban-related problems (e.g., urban sidewalks cracks) and has even been considered as inadequate for planting in urban areas (Conejo, 2011; Moro and Westerkamp, 2011; Vargas-Garzón and Molina-Prieto, 2012), the Weeping Fig has been extensively planted throughout the country since the mid-1990s (Vargas-Garzón and Molina-Prieto, 2012), becoming a dominant urban tree in many cities.

As expected, we recorded a high proportion exotic species. This is consistent with previous studies that have found important number of exotic species dominating urban streetscapes (e.g., 62.8\%: López-Moreno and DíazBetancourt, 1991; 56\%: Kuruneri-Chitepo and Shackleton, 2011; 61.8\%: Ortega-Álvarez et al., 2011; $\geq 50 \%$ : Sjöman et al., 2012; 48.3\%: Wang et al., 2012). The high proportion of exotics in Xalapa is due to the import of plant species from other parts of Mexico and the rest of the world for several reasons (e.g., ornamental, edibility, erosion control; Castillo-Campos, 1991; Eldredge, 2002; Verhoef and Morin, 2010). High tree and shrub species richness recorded in the streetscape of Xalapa is heavily biased by the introduction of exotic species, pattern that has been recorded in cities from around the globe (McKinney, 2008).

Regarding the spatial distribution of the studied tree and shrub species, it was not surprising to find an unequal distribution of species richness values across the city; such pattern has been reported for other urban areas from around the world (Landry and Chakraborty, 2009; Kuruneri-Chitepo and Shackleton, 2011; Kendal et al., 2012). The unequal distribution of greenspaces and woody vegetation across Xalapa has been reported previously by García-Campos (1993) and Lemoine (2012), but to our knowledge, there are no previous studies that report the unequal spatial distribution of woody plant species richness along its streetscapes. Nevertheless, further studies are needed to identify the processes behind this pattern, exploring which variables could be associated with this particular spatial configuration of species richness in Xalapa.

Our results, mainly the unequal distribution of tree and shrub species richness across the streetscape of Xalapa, as well as the high proportion of recorded exotics should be considered carefully, as they have been associated to the irregular distribution of the benefits that vegetation can provide to citizens (Garzón et al., 2004; Escobedo and Nowak, 2009; McConnachie and Shackleton, 2010; Cohen et al., 2012; Kendal et al., 2012). Also, the high proportion of exotic species needs to be considered due to the potential negative effects of such species, including a vast array of detrimental effects that have been documented on local, and even regional, ecological processes (Vitousek et al., 1997; Schmidt and Whelan, 1999; Richardson et al., 2000; McKinney, 2004).

\section{ACKNOWLEDGMENTS}

We are most grateful to Nihaib Flores Galicia for his assistance in the field and with the identification of several 
specimens, to Susana Valencia Ávalos for her kind support with the identification of several Quercus species, and to Gonzalo Castillo Campos for the identification of some specimens and sharing his expertise regarding the identity and origin of the recorded trees and shrubs. We also thank Leila García, Montserrat Solano, Diego Osorio, Dalia Luna, and Ángel Rueda for their assistance in the field. This study was partially funded by the project "Patrones ecológicos y percepción social de la diversidad biológica que habita en la ciudad de Xalapa: Un enfoque multidisciplinario". Ina Falfán acknowledges the scholarship and financial support provided by the National Council of Science and Technology (Conacyt 344590), and the Doctoral Program of the Instituto de Ecología, A.C. (Inecol).

\section{REFERENCES}

Alanís F., G.J. 2005. El arbolado urbano en el área metropolitana de Monterrey. Ciencia UANL 8(1):20-32.

Alberti, M., J.M. Marzluff, E. Shulenberger, G. Bradley, C. Ryan and C. Zumbrunnen. 2003. Integrating humans into ecology: Opportunities and challenges for studying urban ecosystems. BioScience 53(12):1169-1179.

Alcalá, J., M. Sosa, M. Moreno, J. Ortega, C. Quintana and C. Holguin. 2008. Especies arbóreas evaluadas como bioacumuladoras de azufre en la ciudad de Chihuahua, México. Ecología Aplicada 7(1-2):17-21.

Antonini, Y., R.P. Martins, L.M. Aguiar and R.D. Loyola. 2013. Richness, composition and trophic niche of stingless bee assemblages in urban forest remnants. Urban Ecosystems 16(3):527-541.

Ardila, J.P., W. Bijker, V.A. Tolpekin and A. Stein. 2012. Contextsensitive extraction of tree crown objects in urban areas using VHR satellite images. International Journal of Applied Earth Observation and Geoinformation 15(1): 57-69.

Arias H., P.F. 1983. Los árboles de la zona urbana y suburbana de Xalapa. Bachelors's thesis. Universidad Veracruzana. Xalapa, Veracruz. 111 p.

Aronson, M.F.J., F.A. La Sorte, C.H. Nilon, M. Katti, M.A. Goddard, C.A. Lepczyk, P.S. Warren, N.S.G. Williams, S. Cilliers, B. Clarkson, C. Dobbs, R. Dolan, M. Hedblom, S. Klotz, J.L. Kooijmans, I. Kuhn, I.
MacGregor-Fors, M. McDonnell, U. Mortberg, P. Pysek, S. Siebert, J. Sushinsky, P. Werner and M. Winter. 2014. A global analysis of the impacts of urbanization on bird and plant diversity reveals key anthropogenic drivers. Proceedings of the Royal Society B: Biological Sciences 281(1780): 1-8.

Benítez B., G., M.T. Pulido Salas and M. Equihua Z. 2004. Árboles multiusos nativos de Veracruz para reforestación, restauración y plantaciones. Instituto de Ecología, A.C. Xalapa, Veracruz. 288 p.

Berkowitz, A.R., C.H. Nilon and K.S. Hollweg, eds. 2003. Understanding urban ecosystems. A new frontier for science and education. Springer. New York. 523 p.

Berry, B.J.L. 2008. Urbanization. In: J. Marzluff, E. Shulenberger, W. Endlicher, G. Bradley, C. Ryan, C. ZumBrunnen and U. Simon, eds. Urban ecology: an international perspective on the interaction between humans and nature. Springer. New York. p:25-48.

Bobrowski, R. and D. Biondi. 2012. Distribuição e dinâmica da área de copa na arborização de ruas de Curitiba, Paraná, Brasil, no período de 1984-2010. Revista Árvore, Viçosa 36(4):625-635.

Calderón R., G. and J. Rzedowski. 2005. Flora fanerogámica del Valle de México. Instituto de Ecología, A.C., Conabio. Pátzcuaro, Michoacán. 1406 p.

Camacho-Cervantes, M., J.E. Schondube, A. Castillo and I. MacGregor-Fors. 2014. How do people perceive urban trees? Assessing likes and dislikes in relation to the trees of a city. Urban Ecosystems 17(3):761-773.

Capitanachi M., C. and H.S. Amante. 1995. Las áreas verdes urbanas en Xalapa, Veracruz. Catálogo de flora urbana. Universidad Veracruzana, Instituto de Ecología A.C. Xalapa, Veracruz. 524 p.

Capitanachi M., C., E.M. Utrera B. and C.B. Smith. 2001. Unidades ambientales urbanas: Bases metodológicas para la comprensión integrada del paisaje urbano. Universidad Veracruzana, Instituto de Ecología, A.C., Sistema de Investigación del Golfo de México (Conacyt), Xalapa, Veracruz. 276 p.

Castillo-Campos, G. 1991. Vegetación y flora del municipio de Xalapa, Veracruz. Instituto de Ecología, A.C., MAB 
Unesco, H. Ayuntamiento de Xalapa, Veracruz. Xalapa, Veracruz. 148 p.

Chacalo H., A. and V. Corona N.E.. 2009. Árboles y arbustos para ciudades. Universidad Autónoma Metropolitana. México, D.F. 599 p.

Cohen, M., R. Baudoin, M. Palibrk, N. Persyn and C. Rhein. 2012. Urban biodiversity and social inequalities in built-up cities: New evidences, next questions. The example of Paris, France. Landscape and Urban Planning 106(3):277-287.

Conejo G., M. 2011. Análisis de la relación entre las características de los árboles y el daño que causan sobre las banquetas y camellones de la ciudad de Morelia, Michoacán, México. Bachelor's thesis. Universidad Michoacana de San Nicolás de Hidalgo. Morelia, Michoacán. 38 p.

Cruz C., R. 1989. Necesidad de una adecuación del arbolado urbano del Área Metropolitana de la Ciudad de México. In: R. Gío-Argáez, I. Hernández-Ruíz and E. SáinzHernández, eds. Ecología Urbana. Conacyt-SGDSDDFSesic-SEP-UNAM-Secretaría de Desarrollo Urbano, Ecología-UAM. México, D.F. p:67-70.

Czech, B. and P.R. Krausman. 1997. Distribution and causation of species endangerment in the United States. Science 277(5329):1116-1117.

Czech, B., P.R. Krausman and P.K. Devers. 2000. Economic associations among causes of species endangerment in the United States. BioScience 50(7):593-601.

Davies, Z.G., J.L. Edmondson, A. Heinemeyer, J.R. Leake and K.J. Gaston. 2011. Mapping an urban ecosystem service: Quantifying above-ground carbon storage at a city-wide scale: Urban above-ground carbon storage. Journal of Applied Ecology 48(5):1125-1134.

Díaz-Betancourt, M.E. and I.R. López-Moreno. 1993. Las plantas de los jardines privados de Xalapa: Un análisis preliminar. In: I.R. López-Moreno, ed. Ecología urbana aplicada a la ciudad de Xalapa. Instituto de Ecología, A.C., MAB Unesco, H. Ayuntamiento de Xalapa, Veracruz. Xalapa, Veracruz. p: 133-163.

Díaz-Betancourt, M.E., I.R. López-Moreno and E.H. Rapoport. 1987. Vegetación y ambiente urbano en la ciudad de
México. Las plantas de los jardines privados. In: E.H. Rapoport and I.R. López-Moreno, eds. Aportes a la ecología urbana de la ciudad de México. Limusa. México, D.F. p:13-72.

Dwyer, J.F., D.J. Nowak, M.H. Noble and S.M. Sisinni. 2000. Connecting people with ecosystems in the 21 st century. An assessment of our nation's urban forests (Gen. Tech. Rep No. PNW-GTR-490). Department of Agriculture, Forest Service, Pacific Northwest Research Station. Portland, Oregon. 483 p.

Dwyer, J.F., E.G. McPherson, H.W. Schroeder and R.A. Rowntree. 1992. Assessing the benefits and costs of the urban forest. Journal of Arboriculture 18(5):227-234.

Eldredge, N., ed. 2002. Life on earth: an encyclopedia of biodiversity, ecology, and evolution. ABC-CLIO. Santa Barbara, California. 793 p.

Escobedo, F.J. and D.J. Nowak. 2009. Spatial heterogeneity and air pollution removal by an urban forest. Landscape and Urban Planning 90(3-4):102-110.

García-Campos, H.M. 1993. Las áreas verdes públicas de Xalapa. In: I.R. López-Moreno, ed. Ecología urbana aplicada a la ciudad de Xalapa. Instituto de Ecología, A.C., MAB Unesco, H. Ayuntamiento de Xalapa, Veracruz. Xalapa, Veracruz. p:99-132.

Garzón, B., N. Brañes, M.L. Abella and A. Auad.2004. Vegetación urbana y Hábitat Popular: el caso de San Miguel de Tucumán. Revista INVI 18(49): 21-42.

Grimm, N.B., S.H. Faeth, N.E. Golubiewski, C.L. Redman, J. Wu, X. Bai and J.M. Briggs. 2008. Global change and the ecology of cities. Science 319(5864):756-760.

Hope, D., C. Gries, D. Casagrande, C.L. Redman, N.B. Grimm and C. Martin. 2006. Drivers of spatial variation in plant diversity across the Central Arizona-Phoenix ecosystem. Society and Natural Resources 19(2):101-116.

Inegi (Instituto Nacional de Estadística, Geografía e Informática). 2009. Prontuario de información geográfica municipal de los Estados Unidos Mexicanos-Xalapa, Veracruz de Ignacio de la Llave-Clave geoestadística 30087. Inegi. 9 p.

Jim, C.Y. 1988. Street tree study as a theme in urban biogeography. Geography 73(3):226-232. 
Jørgensen, S.E. and B.D. Fath, eds. 2008. Encyclopedia of ecology. Elsevier B.V. Spain. 3834 p.

Kendal, D., N.S.G. Williams and K.J.H. Williams. 2012. Drivers of diversity and tree cover in gardens, parks and streetscapes in an Australian city. Urban Forestry \& Urban Greening 11(3):257-265.

Konijnendijk, C.C. 2008. The forest and the city. The cultural landscape of urban woodland. Springer. New York. 245 p.

Konijnendijk, C., K. Nilsson, T.B. Randrup and J. Schipperijn, eds. 2005. Urban forests and trees. A reference book. Springer. The Netherlands. 520 p.

Kowarik, I. 2011. Novel urban ecosystems, biodiversity, and conservation. Environmental Pollution 159(8-9):1974-1983.

Kuruneri-Chitepo, C. and C.M. Shackleton, 2011. The distribution, abundance and composition of street trees in selected towns of the Eastern Cape, South Africa. Urban Forestry \& Urban Greening 10(3):247-254.

Landry, S.M. and J. Chakraborty. 2009. Street trees and equity: Evaluating the spatial distribution of an urban amenity. Environment and Planning A 41(11):2651-2670.

Lemoine R., R. 2012. Cambios en la cobertura vegetal de la ciudad de Xalapa-Enríquez, Veracruz y zonas circundantes entre 1950 y 2010. Bachelor's thesis. Universidad Veracruzana. Xalapa, Veracruz. 44 p.

Li, Y.Y., X.R. Wang and C.L. Huang. 2011. Key street tree species selection in urban areas. African Journal of Agricultural Research 6(15):3539-3550.

Lintott, P.R., N. Bunnefeld, E. Fuentes-Montemayor, J. Minderman, L.M. Blackmore, D. Goulson and K.J. Park. 2014. Moth species richness, abundance and diversity in fragmented urban woodlands: Implications for conservation and management strategies. Biodiversity and Conservation 23(11):2875-2901.

Lodge, D.M. and K. Shrader-Frechette. 2003. Nonindigenous species: ecological explanation, environmental ethics, and public policy. Conservation Biology 17(1):31-37.

López-Falfán, I.S. 2008. Arbolado urbano en Mérida, Yucatán y su relación con aspectos socioeconómicos, culturales y de la estructura urbana de la ciudad. Master's thesis. Centro de Investigación y de Estudios
Avanzados del Instituto Politécnico Nacional. Mérida, Yucatán. 161 p.

López-Moreno, I.R., ed. 1991. El arbolado urbano de la Zona Metropolitana de la Ciudad de México. UAM-Azcapotzalco, MAB-Unesco, INE A.C. México, D.F. 138 p.

López-Moreno, I.R. and M.E. Díaz-Betancourt. 1989. La introducción de especies en la flora de la Ciudad de México. In: R. Gío-Argáez, I. Hernández-Ruíz and E. Sáinz-Hernández, eds. Ecología urbana. ConacytSGDSDDF-Sesic-SEP -UNAM-Secretaría de Desarrollo Urbano, Ecología-UAM. México, D.F. p:85-92.

López-Moreno, I.R. and M.E. Díaz-Betancourt. 1991. Los árboles de las calles de la ciudad de México. In: I.R. LópezMoreno, ed. El arbolado urbano de la Zona Metropolitana de la Ciudad de México. UAM-Azcapotzalco, MAB-Unesco, INE A.C. México, D.F. p:14-71.

Luck, G.W., L.T. Smallbone and R. O'Brien. 2009. Socioeconomics and vegetation change in urban ecosystems: Patterns in space and time. Ecosystems 12(4):604-620.

MacGregor-Fors, I. 2010. How to measure the urban-wildland ecotone: Redefining "peri-urban" areas. Ecological Research 25(4):883-887.

MacGregor-Fors, I. and R. Ortega-Álvarez, eds. 2013. Ecología urbana: Experiencias en América Latina. Available on line: http://www1.inecol.edu.mx/libro_ecologia_urbana/. ISBN: 978-607-00-6869-0.

MacGregor-Fors, I., S. Avendaño-Reyes, V.M. Bandala, S. Chacón-Zapata, M.H. Díaz-Toribio, F. González-García, F. Lorea-Hernández, J. Martínez-Gómez, E. Montes de Oca, L. Montoya, E. Pineda, L. Ramírez-Restrepo, E. Rivera-García, E. Utrera-Barrillas and F. Escobar. 2015. Multi-taxonomic diversity patterns in a neotropical green city: A rapid biological assessment. Urban Ecosystems $18: 633-647$

Manning, W. 2008. Plants in urban ecosystems: Essential role of urban forests in urban metabolism and succession toward sustainability. International Journal of Sustainable Development \& World Ecology 15(4):362-370.

McCaffrey, R.E. and R.W. Mannan. 2012. How scale influences birds' responses to habitat features in urban residential areas. Landscape and Urban Planning 105(3):274-280. 
McConnachie, M.M. and C.M. Shackleton. 2010. Public green space inequality in small towns in South Africa. Habitat International 34(2):244-248.

McKinney, M.L. 2004. Measuring floristic homogenization by non-native plants in North America. Global Ecology and Biogeography 13(1):47-53.

McKinney, M.L. 2006. Urbanization as a major cause of biotic homogenization. Biological Conservation 127(3):247-260.

McKinney, M.L. 2008. Effects of urbanization on species richness: A review of plants and animals. Urban Ecosystems 11(2):161-176.

McPherson, E.G., D. Nowak, G. Heisler, S. Grimmond, C. Souch, R. Grant and R. Rowntree. 1997. Quantifying urban forest structure, function, and value: the Chicago Urban Forest Climate Project. Urban ecosystems 1(1):49-61.

Moro, M.F. and C. Westerkamp. 2011. The alien street trees of Fortaleza (NE Brazil): Qualitative observations and the inventory of two districts. Ciência Florestal 21(4):789-798.

Nagendra, H. and D. Gopal. 2010. Street trees in Bangalore: Density, diversity, composition and distribution. Urban Forestry \& Urban Greening 9(2):129-137.

Niembro-Rocas, A. 1992. La flora de la ciudad de Campeche. $\mathrm{Su}$ origen, composición, distribución e importancia. Universidad Autónoma de Campeche. Campeche, Campeche. 75 p.

Nilon, C.H., P.S. Warren and J. Wolf. 2011. Baltimore birdscape study: identifying habitat and land-cover variables for an urban bird-monitoring project. Urban Habitats 6(1). Available on line: http://www.urbanhabitats.org/v06n01/ baltimore_full.html

Orellana, R., L. Carrillo and V. Franco. 2003. Árboles recomendados para la ciudad de Mérida. La naturaleza como parte del contexto urbano. Jardín Botánico Regional, Ayuntamiento de Mérida, PNUD, FMAM, CICY. México. 70 p.

Ortega-Álvarez, R. and I. MacGregor-Fors. 2011. Dusting-off the file: A review of knowledge on urban ornithology in Latin America. Landscape and Urban Planning 101(1):1-10.

Ortega-Álvarez, R., H.A. Rodríguez-Correa and I. MacGregorFors. 2011. Trees and the city: Diversity and composition along a neotropical gradient of urbanization. International Journal of Ecology 2011:1-8.

Pauchard, A. and O. Barbosa. 2013. Regional assessment of Latin America: Rapid urban development and social economic inequity threaten biodiversity hotspots. In: T. Elmqvist, M. Fragkias, J. Goodness, B. Güneralp, P.J. Marcotullio, R.I. McDonald, S. Parnell, M. Schewenius, M. Sendstad, K.C. Seto and C. Wilkinson, eds. Urbanization, biodiversity and ecosystem services: Challenges and opportunities. Springer. Dordrecht. p:588-608.

Pennington, T. D. and J. Sarukhán. 2005. Árboles tropicales de México. Manual para la identificación de las principales especies. 3 a ed. Universidad Nacional Autónoma de México, Fondo de Cultura Económica. México, D.F. 523 p.

Pickett, S.T.A., M.L. Cadenasso, J.M. Grove, C.G. Boone, P.M. Groffman, E. Irwin, S.S. Kaushal, V. Marshall, B.P. McGrath, C.H. Nilon, R.V. Pouyat, K. Szlavecz, A. Troy and P. Warren. 2011. Urban ecological systems: Scientific foundations and a decade of progress. Journal of Environmental Management 92(3):331-362.

R Development Core Team. 2012. R version 2.15.2. http:// www.R-project.org.

Ramage, B.S., L.A. Roman and J.S. Dukes. 2013. Relationships between urban tree communities and the biomes in which they reside. Applied Vegetation Science 16(1):8-20.

Ramírez-Restrepo, L. and G. Halffter. 2013. Butterfly diversity in a regional urbanization mosaic in two Mexican cities. Landscape and Urban Planning 115(1):39-48.

Richardson, D.M., P. Pyšek, M. Rejmánek, M.G. Barbour, F.D. Panetta and C.J. West. 2000. Naturalization and invasion of alien plants: Concepts and definitions. Diversity and Distributions 6(2):93-107.

Rowntree, R.A. 1984. Ecology of the urban forest - Introduction to part I. Urban Ecology 8(1):1-11.

Ruiz-Montiel, C., V. Vázquez-Torres, M.J. MartínezHernández, L. Murrieta-Pérez and M.S. Perea-Hernández. 2014. Árboles y arbustos registrados en el Parque Ecológico Molino de San Roque. Madera y Bosques 20(2):143-152. 
Sánchez, X.M. and M.G. Peralta. 2013. Árboles de las áreas urbanas y suburbanas de Morelia, Michoacán, México. Biológicas 9(1):12-22.

Schmidt, K.A. and C.J. Whelan. 1999. Effects of exotic Lonicera and Rhamnus on songbird nest predation. Conservation Biology 13(6):1502-1506.

Sjöman, H., J. Östberg, and O. Bühler. 2012. Diversity and distribution of the urban tree population in ten major Nordic cities. Urban Forestry \& Urban Greening 11(1):31-39.

Sosa, V. and J.S. Flores. 1993. La flora ornamental de Mérida. Ayuntamiento de Mérida. Mérida, Yucatán. 265 p.

Soto E., M. and C.M. Gómez. 1993. Consideraciones climáticas de la ciudad de Xalapa. In: I.R. López-Moreno, ed. Ecología urbana aplicada a la ciudad de Xalapa. Instituto de Ecología, A.C., MAB Unesco, H. Ayuntamiento de Xalapa, Veracruz. Xalapa, Veracruz. p:81-98.

Subburayalu, S. and T.D. Sydnor. 2012. Assessing street tree diversity in four Ohio communities using the weighted Simpson index. Landscape and Urban Planning 106(1):44-50

SCDEPEV (Subcomisión de Conservación y Desarrollo del Espacio Público del Estado de Veracruz). 2010. Conservación y desarrollo sostenible del patrimonio arbóreo de la ciudad de Xalapa: Principales parques, avenidas, calles, campus universitarios, jardines institucionales y entorno al “Sistema de los Lagos y el Dique universitarios" (Inventario arbóreo georeferenciado en CD). Xalapa, Veracruz.

Thaiutsa, B., L. Puangchit, R. Kjelgren and W. Arunpraparut. 2008. Urban green space, street tree and heritage large tree assessment in Bangkok, Thailand. Urban Forestry \& Urban Greening 7(3):219-229.

Turner, W.R. 2003. Citywide biological monitoring as a tool for ecology and conservation in urban landscapes: The case of the Tucson Bird Count. Landscape and Urban Planning 65(3):149-166.

Tyrväinen, L., S. Pauleit, K. Seeland and S. de Vries. 2005. Benefits and uses of urban forests and trees. In: C. Konijnendijk, K. Nilsson, T.B. Randrup and J. Schipperijn, eds. Urban forests and trees. A reference book. Springer. The Netherlands. p:81-114.
United Nations, 2014. World urbanization prospects: the 2014 revision. Highlights. UN. New York. 32 p.

Vargas-Garzón, B. and L.F. Molina-Prieto. 2012. Ficus benjamina L. in the cities: High number of individuals, severe damages to infrastructure and expensive economic losses. Nodo: Arquitectura. Ciudad. Medio Ambiente 7(13):93-101.

Vázquez T., M. 2007. Los árboles cultivados de Veracruz. Secretaría de Educación de Veracruz, Instituto Veracruzano de la Cultura, Consejo Veracruzano de Ciencia y Tecnología, Universidad Veracruzana. Xalapa, Veracruz. 279 p.

Verhoef, H.A. and P.J. Morin, eds. 2010. Community ecology: process, models and applications. Oxford University Press. Oxford. 247 p.

Vitousek, P.M., H.A. Mooney, J. Lubchenco and J.M. Melillo. 1997. Human domination of Earth's ecosystems. Science 277(5325):494-499.

Vlahov, D. and S. Galea. 2002. Urbanization, urbanicity, and health. Journal of Urban Health 79(4):1-12.

Wang, H.F., I. MacGregor-Fors and J. López-Pujol. 2012. Warm-temperate, immense, and sprawling: Plant diversity drivers in urban Beijing, China. Plant Ecology 213(6): 967-992.

Williams-Linera, G., R.H.Manson and E. Isunza-Vera. 2002. La fragmentación del bosque mesófilo de montaña y patrones de uso del suelo en la región oeste de Xalapa, Veracruz, México. Madera y Bosques 8(1):73-89.

Yang, J., J. Zhou, Y. Ke and J. Xiao. 2012. Assessing the structure and stability of street trees in Lhasa, China. Urban Forestry \& Urban Greening 11(4):432-438.

Zipperer, W.C., S.M. Sisinni, R.V. Pouyat and T.W. Foresman. 1997. Urban tree cover: An ecological perspective. Urban Ecosystems 1(4):229-246.

Manuscrito recibido el 30 de abril de 2015. Aceptado el 15 de diciembre de 2015.

Este documento se debe citar como:

Falfán, I. and MacGregor-Fors, I. 2016. Woody neotropical streetscapes: a case study of tree and shrub species richness and composition in Xalapa. Madera y Bosques 22(1):95-110. 